\title{
Mud volcanoes and ice-keel ploughmarks, Beaufort Sea shelf, Arctic Canada
}

\author{
J. A. DOWDESWELL ${ }^{1 *} \&$ B. J. TODD ${ }^{2}$ \\ ${ }^{1}$ Scott Polar Research Institute, University of Cambridge, Cambridge CB2 1ER, UK \\ ${ }^{2}$ Geological Survey of Canada, Natural Resources Canada, P.O. Box 1006, Dartmouth, Nova Scotia, Canada B2Y $4 A 2$ \\ *Corresponding author (e-mail:jd16@cam.ac.uk)
}

The shallow shelf waters of the Beaufort Sea have experienced marine transgression during the Holocene (Hill et al. 1985; Blasco et al. 1990; Taylor et al. 2013). This has led to a warming of what was terrestrial permafrost by water incursion, and to the dissociation of subsurface gas hydrates which now vent into marine waters. Accompanying this change is the development of conical submarine landforms produced through the extrusion of sediments, combined with the continuing reworking of the seafloor by the ploughing action of the keels of drifting ice (Fig. 1).

\section{Description}

Conical mounds, circular in planform, are present on the seafloor of the Beaufort Sea shelf, Arctic Canada (Fig. 1c), in water depths of $<100 \mathrm{~m}$ (Fig. 1a, b; Paull et al. 2007). These features occur either as isolated discrete mounds or in fields or swarms. The single discrete mounds are up to $30 \mathrm{~m}$ high with a base diameter of $400-500 \mathrm{~m}$ and slope angles of $8-10^{\circ}$ (Fig. 1d, e). In some instances, these mounds are circumscribed by an annulus or moat that can reach a few metres in depth and 100-200 $\mathrm{m}$ in width. Some moats encircle their associated conical mounds whereas others only flank one portion of total mound circumference.

Where fields of conical mounds are imaged (Fig. 1b), they include small to large relatively symmetrical mounds, usually associated with annular moats. There is a range of mound sizes with heights reaching 30-40 $\mathrm{m}$ and base diameters up to $600 \mathrm{~m}$, measured across wellformed annular moats (Fig. 1b). Some mounds appear to have irregularly shaped sides, and without well-developed moats. Several such degraded mounds are imaged in the southeastern part of Figure $1 b$.

In some locations, linear and curvilinear features are also present on the seafloor in the region of the conical mounds (Fig. 1a). These seafloor features are up to $2 \mathrm{~m}$ deep and $60 \mathrm{~m}$ wide and can be traced up to lengths of $10 \mathrm{~km}$ to the limit of the multibeam sonar imagery (Fig. 1a, d). The erosive nature of these features is evident from their cross-cutting nature, implying an older relative age for the segment that has been cross-cut (Fig. 1a). In some instances, the seafloor trace of the linear and curvilinear features is lost where they intersect conical mounds and associated moats, implying subsequent burial.

\section{Interpretation}

The conical mounds are interpreted to be mud volcanoes associated with the release of methane from gas hydrates. Similar features elsewhere on the Beaufort Shelf have been referred to as pingo-like mounds (Shearer et al. 1971; Paull et al. 2007) because of their morphological similarity to subaerial conical ice-cored mounds known as pingos (Mackay 1998).

The mud volcanoes are proposed to have formed by methane release and bubble formation linked to dissociating gas hydrates at depth (Kopf 2002; Paull et al. 2007). Venting produces gas-expansion voids and over-pressuring, leading to upward extrusion of sediment to form the mounds. The adjacent moats develop as gas venting and subsurface volume loss through sediment entrainment continues, producing collapse and moats around the mounds. The moats are then infilled by subsequent marine sedimentation (Paull et al. 2007), with deposition in the moats resulting, in part at least, from the current-flow obstruction presented by the volcanoes. Gas venting is suggested to take place as a result of thermal warming of subsurface gas hydrates linked to Holocene transgression associated with relative sea-level rise of about $70 \mathrm{~m}$ and flooding of the previously subaerial and very cold, emergent Beaufort Shelf (Hill et al. 1985).

Mud-volcano morphology varies in freshness. Mounds with a fresh and symmetrical appearance, and associated well-formed moats (Fig. expulsion is the mechanism that builds cone volume. Those mud volcanoes with less regular, degraded flanks are relatively older and probably no longer active, with their sides becoming subject to slope failures. Their moats can also become infilled by marine sedimentation in the absence of continuing subsurface volume loss. Fields of active and decaying mud volcanoes indicate that the flow pathways of gas and sediment from the subsurface to the seafloor change with time. Radiocarbon dates from biogenic material suggest that the mud volcanoes probably formed between about 1 and $4.5 \mathrm{kyr}$ ago, in the later Holocene (Paull et al. 2007), with many continuing to be active today.

Linear to curvilinear seafloor depressions, similar to those observed among the mud volcanoes of the Beaufort Shelf, have long been regarded as the signature of seafloor ploughing by the keels of sea-ice floes or icebergs (e.g. Hequette et al. 1995; Blasco et al. 1998; Pelletier \& Shearer 1972; Woodworth-Lynas et al. 1991). The relatively small numbers of ploughmarks imaged at 60 to $70 \mathrm{~m}$ water depth (Fig. 1a) contrast with the heavily sea-ice ploughed seafloor at shallower depths of a few tens of metres on the Beaufort Shelf (e.g. Hequette et al. 1995; Blasco et al. 1998). There are almost no sources of icebergs, which can have relatively deep keels, to the waters of the western Canadian Arctic either now or during most of the Holocene. This implies that the ploughmarks in Figure 1a were probably produced by highly ridged sea-ice floes with unusually deep keels, although the ploughing action of small numbers of far-travelled icebergs cannot be excluded.

\section{References}

BLASCO, S. M., FORTIN, G., HILl, P. R., O'CONNOR, M. J. \& BRIGHAM-GRETTE, J. 1990. The late Neogene and Quaternary stratigraphy of the Canadian Beaufort continental shelf. In: Grantz, A., Johnson, L. \& Sweeney, J. F. (eds) The Geology of North America, vol. L, The Arctic Ocean Region, Geological Society of America, Boulder, Colorado, 491-502.

BLASCO, S. M., SHEARER, J. M. \& MYERS, R. 1998. Seabed scouring by sea-ice; scouring process and impact rates; Canadian Beaufort shelf. 13th International Symposium on Okhotsk Sea and Sea Ice, Center for Cold Ocean Resources and Engineering, Mombetsu, Japan.

HÉQUeTTE, A., DESROSIERS, M. \& BARNES, P. W. 1995. Sea ice scouring on the inner shelf of the southeastern Canadian Beaufort Sea. Marine Geology, 128, 201-219, doi: 10.1016/0025-3227(95)00095-G.

HILL, P. R., MUDIE, P. J., MORAN, K. \& BLASCO, S. M. 1985. A sea-level curve for the Canadian Beaufort Shelf. Canadian Journal of earth Sciences, 22, 1383-1393.

KOPF, A. J. 2002. Significance of mud volcanism. Reviews of Geophysics, 40 , 2-1-2-52, doi:10.1029/2000RG000093.

MACKAY, J. R. 1998. Pingo growth and collapse, Tuktoyaktuk Peninsula area, western Arctic coast, Canada; a long-term field study. Geographie Physique et Quaternaire, 52, 271-323.

PAULL, C. K., USSLER III, W. et al. 2007. Origin of pingo-like features on the Beaufort Sea shelf and their possible relationship to decomposing methane gas hydrates. Geophysical Research Letters, 34, L01603, doi: 10.1029/2006GL027977.

PELLETIER, B. R. \& and SHEARER, J. M. 1972. Sea bottom scouring in the Beaufort Sea of the Arctic Ocean. 24th International Geological Congress, Mar. section 8, Geology and Geophysics, Montreal, Canada, 251-261.

SHEARER, J. M., MACNAB, R. F., PELLETIER, B. R. \& SMITH T. B. 1971. Submarine pingos in the Beaufort Sea. Science, 174, 816-181.

TAYLOR, A. E., DALLIMORE, S. R., HILL, P. R., ISSLER, D. R., BLASCO, S. \& WRIGHT, F. 2013. Numerical model of the geothermal regime on the Beaufort Shelf, Arctic Canada since the Last Interglacial. Journal of Geophysical Research, 118, 2365-2379

WOODWORTH-LYNAS, C. M. T., JOSENHANS, H. W., BARRIE, J. V., LEWIS, C. F. M. \& PARROTT, D. R. 1991. The physical processes of seabed disturbance during iceberg grounding and scouring. Continental Shelf Research, 11, 939-951. 


\section{J. A. DOWDESWELL \& B. J. TODD}

Fig.1. Multibeam swath bathymetry and bathymetric profiles of mud volcanoes and ice-keel ploughmarks on the Beaufort Sea shelf, Arctic Canada. (a) Sunilluminated multibeam-bathymetric image showing mud volcanoes and ice-keel ploughmarks. Acquisition system Kongsberg EM302. Frequency $30 \mathrm{kHz}$. Grid-cell size $5 \mathrm{~m}$. White arrows denote a curvilinear ploughmark cross-cutting its previous track. The image is a compilation of data from two vessels. The NW-SE narrow, linear artefacts arise from instrumentation employed in the initial survey. Wide, curvilinear artefacts arise from different instrumentation employed in a subsequent survey. (b) Sun-illuminated multibeam-bathymetric image showing a field of mud volcanoes. Acquisition system Kongsberg EM3002. Frequency $300 \mathrm{kHz}$. Grid-cell size $5 \mathrm{~m}$. (c) Location of study area (red box; map from IBCAO v. 3.0). (d) Bathymetric profile $\mathrm{x}-\mathrm{x}^{\prime}$ of mud volcano and ice-keel ploughmark in (a). VE x 11. (e) Bathymetric profile y-y' through a field of mud volcanoes in (b). VE x 11. 

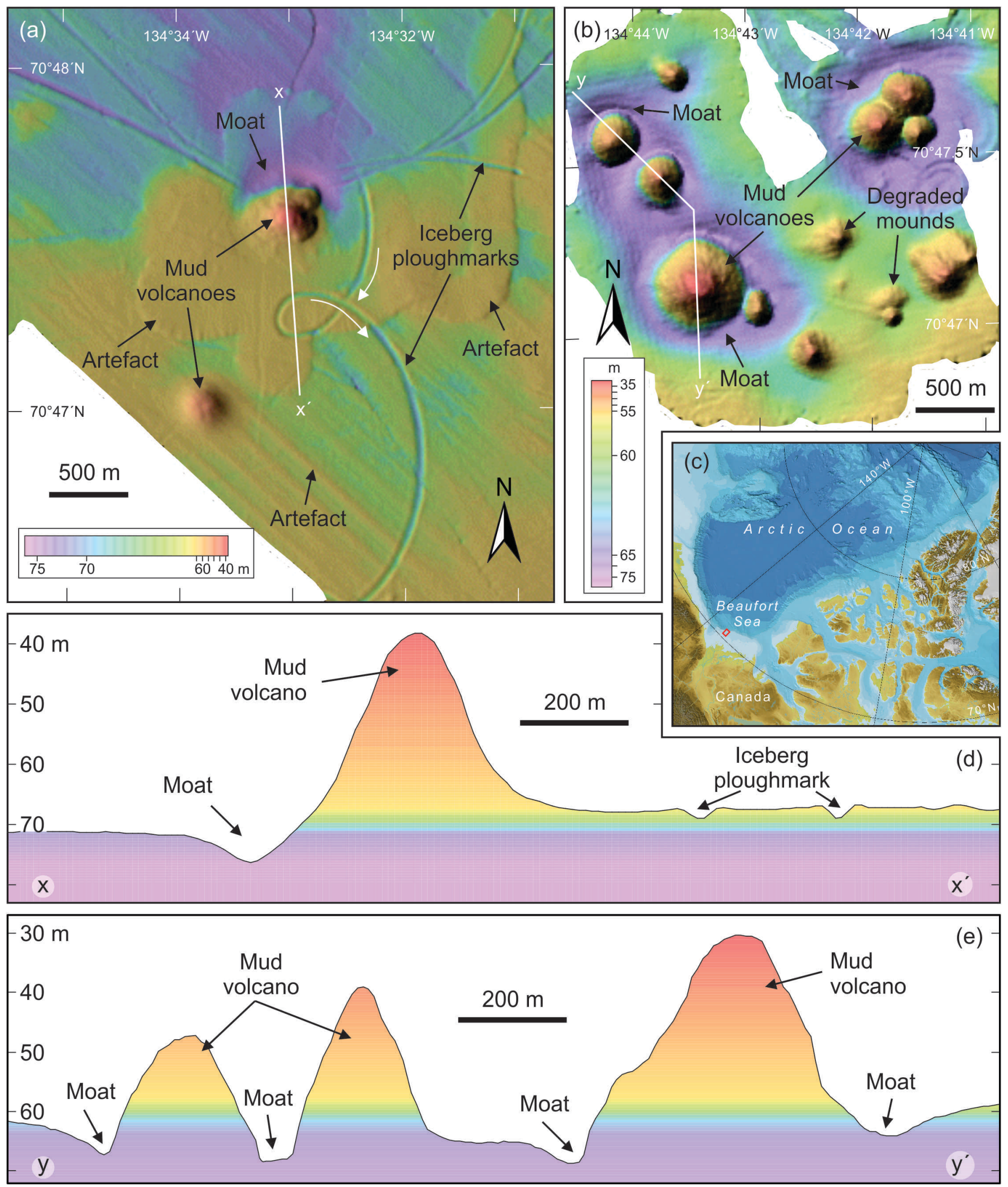